Article

\title{
Genetic Attenuation of Paraoxonase 1 Activity Induces Proatherogenic Changes in Plasma Proteomes of Mice and Humans
}

\author{
Marta Sikora ${ }^{1}$, Ewa Bretes ${ }^{2}{ }^{(0)}$, Joanna Perła-Kaján ${ }^{2}{ }^{-}$, Izabela Lewandowska ${ }^{1,3}$, \\ Lukasz Marczak ${ }^{1}$ and Hieronim Jakubowski ${ }^{2,3, *(D)}$ \\ 1 European Centre for Bioinformatics and Genomics, Institute of Bioorganic Chemistry, 61-704 Poznań, Poland; \\ mperdziak@yahoo.com (M.S.); izek1988@gmail.com (I.L.); lukasmar@ibch.poznan.pl (Ł.M.) \\ 2 Department of Biochemistry and Biotechnology, Poznań University of Life Sciences, 60-632 Poznań, Poland; \\ ewa.bretes@up.poznan.pl (E.B.); asiape1@gmail.com (J.P.-K.) \\ 3 International Center for Public Health, Department of Microbiology, Biochemistry and Molecular Genetics, \\ Rutgers University-New Jersey Medical School, Newark, NJ 07103, USA \\ * Correspondence: jakubows@rutgers.edu or jakubows2@gmail.com; Tel.: +973-972-8733; Fax: +973-972-8982
}

Received: 31 October 2020; Accepted: 25 November 2020; Published: 28 November 2020

\begin{abstract}
High-density lipoprotein (HDL), in addition to promoting reverse cholesterol transport, possesses anti-inflammatory, antioxidative, and antithrombotic activities. Paraoxonase 1 (PON1), carried on HDL in the blood, can contribute to these antiatherogenic activities. The PON1-Q192R polymorphism involves a change from glutamine ( $Q$ variant) to arginine ( $R$ variant) at position 192 of the PON1 protein and affects its enzymatic activity. The molecular basis of PON1 association with cardiovascular and neurological diseases is not fully understood. To get insight into the function of PON1 in human disease, we examined how genetic attenuation of PON1 levels/activity affect plasma proteomes of mice and humans. Healthy participants (48.9 years old, 50\% women) were randomly recruited from the Poznań population. Four-month-old Pon1 ${ }^{-/-}(n=17)$ and Pon $1^{+/+}$ $(n=8)$ mice ( $50 \%$ female) were used in these experiments. Plasma proteomes were analyzed using label-free mass spectrometry. Bioinformatics analysis was carried out using the Ingenuity Pathway Analysis (IPA) resources. PON1-Q192R polymorphism and Pon1 $1^{-/}$genotype induced similar changes in plasma proteomes of humans and mice, respectively. The top molecular network, identified by IPA, affected by these changes involved proteins participating in lipoprotein metabolism. Other PON1 genotype-dependent proteomic changes affect different biological networks in humans and mice: "cardiovascular, neurological disease, organismal injury/abnormalities" in PON1-192QQ humans and "humoral immune response, inflammatory response, protein synthesis" and "cell-to-cell signaling/interaction, hematological system development/function, immune cell trafficking" in Pon1 $^{-/}$mice. Our findings suggest that PON1 interacts with molecular pathways involved in lipoprotein metabolism, acute/inflammatory response, and complement/blood coagulation that are essential for blood homeostasis. Modulation of those interactions by the PON1 genotype can account for its association with cardiovascular and neurological diseases.
\end{abstract}

Keywords: PON1 genotype; plasma proteomes; lipoproteins; atherosclerosis; humans; mice

\section{Introduction}

Inflammation promotes several key events during the development of atherosclerosis. High-density lipoprotein (HDL), in addition to promoting reverse cholesterol transport, has also been reported to possess anti-inflammatory, antioxidative, and antithrombotic activities important for its atheroprotective function [1]. A calcium-dependent hydrolytic enzyme, paraoxonase 1 (PON1), 
carried on HDL in the blood, has been suggested to contribute to these antiatherogenic activities $[2,3]$. The PON1 gene has several polymorphisms, including the Q192R, which involves a change from glutamine (Q variant) to arginine ( $R$ variant) at position 192 of the amino acid sequence of the PON1 protein and affects its hydrolytic activity [4]. Historically, the hydrolytic activity of the PON1 enzyme has been measured with non-natural substrates such as the organophosphate paraoxon (for which the PON1 enzyme has been named) and phenyl acetate, which have been considered as surrogates for an unknown endogenous substrate that promotes atherogenesis [5]. One such endogenous substrate of PON1, homocysteine thiolactone [6], which can adversely impact protein structure/function by posttranslational modification [7], has been recently shown to be a predictor of myocardial infarction in coronary artery disease patients [8]. Levels of Hcy-thiolactone are higher in low-activity PON1-192QQ than in high-activity PON1-192RR individuals [9]. Hcy-thiolactonase and paraoxonase (POase) activities of PON1 are strongly correlated [10,11], suggesting that the nonphysiological POase is a good surrogate for the physiological Hcy-thiolactonase activity.

Accumulating evidence from human studies and animal models suggests that antiatherogenic and cardioprotective effects of HDL are largely attributable to PON1 [12]. For example, induction of hyperlipidemia, either by a high-fat diet or ApoE gene deletion, increases atherosclerotic lesion size in Pon $1^{-/-}$mice compared with Pon $1^{+/+}$animals $[13,14]$. Overexpression of the human PON1 transgene in these animals reduces aortic lesion size and decreases epitopes recognized by antibodies specific for oxidized lipid-protein adducts [15]. In humans, individuals with the low activity PON1-192QQ genotype have an increased risk of all-cause mortality and of major adverse cardiac events [16]. Individuals with the highest PON1 activity quartile, the majority of which have PON1-192RR genotype, had lower incidence of major adverse cardiac events compared with those in the lowest activity quartile. PON1 activity is associated with cardiovascular risk independent of several established risk factors except for HDL cholesterol [17]. This association is attenuated by adjusting for HDL cholesterol, which is expected because PON1 is an important component of HDL.

PON1 has also been implicated in Alzheimer's disease (AD) [18], which is expected given that AD has a significant vascular component. For example, genomic association studies show that a single-nucleotide polymorphism in the PON1 gene is a risk factor for AD [19]. Other studies show that low PON1 activity is also linked to the risk of AD and dementia [20,21]. In mice, deletion of the Pon1 $^{-/}$gene makes the animals overly sensitive to the neurotoxicity of Hcy-thiolactone [22].

The molecular basis of the involvement of PON1 in CVD and AD is not fully understood. To get insight into the function of PON1 in human disease, in the present work we have used label-free mass spectrometry and the Ingenuity Pathway Analysis to examine how genetic attenuation of PON1 levels/activity affect plasma proteomes of mice and humans.

\section{Materials and Methods}

\subsection{Participants}

The present study included healthy participants randomly selected from the Poznań population ( $n=100,48.9$ years old, 48.9\% women). Participant characteristics for the whole group and for each PON1-Q192R polymorphism are described in Supplementary Table S1. All participants had signed an informed consent. The study was approved by the Bioethics Committee of the Poznan University of Medical Sciences (approval No. 661/16, approved 16 June 2016).

\subsection{Mice and Diet}

Pon $^{-/-}$mice [13] and wild-type Pon1 ${ }^{+/+}$littermates (C57BL/6J) were maintained at the Rutgers University, New Jersey Medical School Animal Facility. Mice of both sexes (Pon1 ${ }^{-/-}, n=17 ;$ Pon $1^{+/+}$, $n=8$ ) were fed a normal rodent chow (LabDiet 5010, Purina Mills International, St. Louis, MO, USA). The animal procedures were approved by the Institutional Animal Care and Use Committee (Protocol \#16114D0320, approved 29 March 2017). 


\subsection{Blood Collection}

Human blood was drawn by venous puncture into EDTA tubes. Mouse blood was collected from the cheek vein into Eppendorf tubes containing $1 \%(v / v) 0.5 \mathrm{M}$ EDTA. After centrifugation $(2000 \times g$, $15 \mathrm{~min}, 4^{\circ} \mathrm{C}$ ), cleared plasma and cell pellets were frozen at $-80^{\circ} \mathrm{C}$. Blood was also collected into serum tubes, allowed to clot for $30 \mathrm{~min}$, serum separated, and stored as above.

\subsection{Genotyping}

Genomic DNA was extracted from whole human or mouse blood using the phenol extraction method and stored at $-80^{\circ} \mathrm{C}$. The human PON1 locus was genotyped by PCR-RFLP as previously described [10] following the procedure of Humbert et al. [23]. The PON1-192 alleles were amplified using the primers $5^{\prime}$-TATTGTTGCTGTGGGACCTG-3' and 5'-GTTCACATACTTGCCATCGG- ${ }^{\prime}$ ' at an annealing temperature of $59^{\circ} \mathrm{C}$ for 30 cycles. The $202 \mathrm{bp} \mathrm{PCR} \mathrm{products} \mathrm{were} \mathrm{digested} \mathrm{with}$ Mbol (Thermo Fisher Scientific, Waltham, MA, USA) and analyzed by $4 \%$ agarose gel electrophoresis. Two bands (160 bp and $42 \mathrm{bp}$ ) indicate the PON1-192Q allele while three bands (132, 42, and $28 \mathrm{bp}$ ) signify the PON1-192R allele.

The mouse Pon1 locus was genotyped by PCR as described [13] using the forward primer p1 (5'-TGGGCTGCAGGTCTCAGGACTGA-3'), exon 1 reverse primer p2 (5'-ATAGGAAGACCG ATGGTTCT-3'), and neomycin cassette reverse primer 33 (5'-TCCTCGTGCTTTACGGTATCG-3') [13]. The $144 \mathrm{bp}$ amplicon from the Pon $1^{+/+}$wild-type allele (obtained with p1, p2 primers) and the $240 \mathrm{bp}$ amplicon from the Pon1 $1^{-/}$allele (obtained with $\mathrm{p} 1$, $\mathrm{p} 3$ primers) were separated on $1.5 \%$ agarose gels and visualized by staining with SYBRSafe (Invitrogen).

\subsection{PON1 Activity Assays}

PON1 activity was quantified in human and mouse sera using paraoxon or phenyl acetate as substrates as previously described $[6,9,11,24]$.

\subsection{Label-Free Mass Spectrometry}

Ten micrograms of human or mouse plasma protein were diluted in $50 \mathrm{mM}$ ammonium bicarbonate $(15 \mu \mathrm{L})$, reduced with dithiothreitol $\left(5.5 \mathrm{mM}, 5 \mathrm{~min}, 95^{\circ} \mathrm{C}\right)$, and alkylated with iodoacetamide $(5 \mathrm{mM}$, $20 \mathrm{~min}, 25^{\circ} \mathrm{C}$, in the dark). Proteins were digested with Promega sequencing-grade trypsin $(0.2 \mu \mathrm{g}$, overnight, $37^{\circ} \mathrm{C}$ ), separated using the Dionex UltiMate 3000 RSLC nanoLC System and analyzed using Q Exactive Orbitrap mass spectrometer (Thermo Fisher Scientific) as previously described [25].

\subsection{Data Analysis}

Datasets were imported into MaxQuant 1.5.3.30 version. Proteins were identified using UniProt human/mouse database with a precision tolerance $10 \mathrm{ppm}$ for peptide masses and $0.08 \mathrm{Da}$ for fragment ion masses as previously described [25]. The MaxQuant data were filtered for reverse identifications (false positives), contaminants, and proteins "only identified by site". Perseus software (version 1.4.1.3, MPIB, Martinsried, Germany) was used for label-free quantification (LFQ) of peptide intensities. The mean LFQ intensities +/- standard deviation were calculated for each identified differentially expressed protein. The fold change values (FC) for the PON1 genotype-affected proteins were calculated from the mean LFQ intensities for each genotype.

\subsection{Statistics}

Proteins were considered to be PON1 genotype-dependent if at least two peptides with $>99 \%$ confidence were identified and the FC between PON1 genotype groups was statistically significant $(p<0.05)$. Numeric data were log-transformed and filtered. For multiple comparisons, one-way analysis of variance (ANOVA) with a Bonferroni correction for multiple testing was carried out. PON1 genotype-affected proteins were normalized using Z-score algorithm. T-test was used for 
comparisons between two groups with $p$ values $<0.05$ considered significant. Multivariate analyses were carried out by untargeted principal component analysis (PCA) [25].

\subsection{Bioinformatics Analysis}

The datasets containing differentially expressed proteins were uploaded into the IPA Knowledge database. Biological pathways and networks involving PON1 genotype-affected proteins were identified using the Ingenuity Pathway Analysis resources (IPA, Ingenuity Systems, Mountain View, CA, USA) as previously described [25].

\section{Results}

The effects of the PON1 genotype on PON1 activity and protein levels in humans and mice are shown in Table 1. As expected, deletion of the Pon1 gene had a severe effect on Pon1 protein and activity levels in mice, with essentially complete absence of both Pon1 protein and activity $[6,13,22]$. In contrast, the PON1-Q192R polymorphism on PON1 function in humans was relatively mild with about $40 \%$ reduction in PON1 protein and fivefold reduction in PON1 activity.

Table 1. PON1 genotype, activity, and protein levels in humans and mice.

\begin{tabular}{cccccc}
\hline \multicolumn{2}{c}{ Human Paraoxonase 1 } & \multicolumn{3}{c}{ Mouse Paraoxonase 1 } \\
\hline Genotype (n) & Activity $^{\mathbf{a}}$ & Protein $^{\mathbf{b}}$ & Genotype (n) Activity $^{\mathbf{a}}$ & Protein $^{\mathbf{b}}$ \\
\hline PON1-192RR (19) & 100 & 100 & $\operatorname{Pon1}^{+/+}(17)$ & 100 & 100 \\
\hline PON1-192QR (30) & 20.6 & 63.0 & & & \\
\hline$P O N 1-192 Q Q(51)$ & 14.3 & 60.0 & Pon1 $^{-/-}(8)$ & 0.0 & 2.0 \\
\hline
\end{tabular}

a Relative mean values determined in serum using paraoxon as a substrate. ${ }^{\mathrm{b}}$ Relative mean values calculated from label-free mass spectrometry data for PON1 shown in Supplementary Table S2.

In each group of human participants and mice, label-free nanoLC-MS/MS mass spectrometry identified 196-198 plasma proteins with a minimum of two peptides and $1 \%$ false discovery rate (FDR). Proteome Discoverer (PD) analysis showed $>90 \%$ overlap at the protein level between duplicate runs.

The variation between samples in terms of global proteomic profiles was assessed using the principal component analysis (PCA). There was a clear difference in PCA profiles between Pon1 $1^{-1-}$ mice and their Pon $1^{+/+}$siblings (Figure 1A). However, there was an overlap in PCA profiles between humans with PON1-192QQ, PON1-192QR, and PON1-192RR genotypes (Figure 1B).

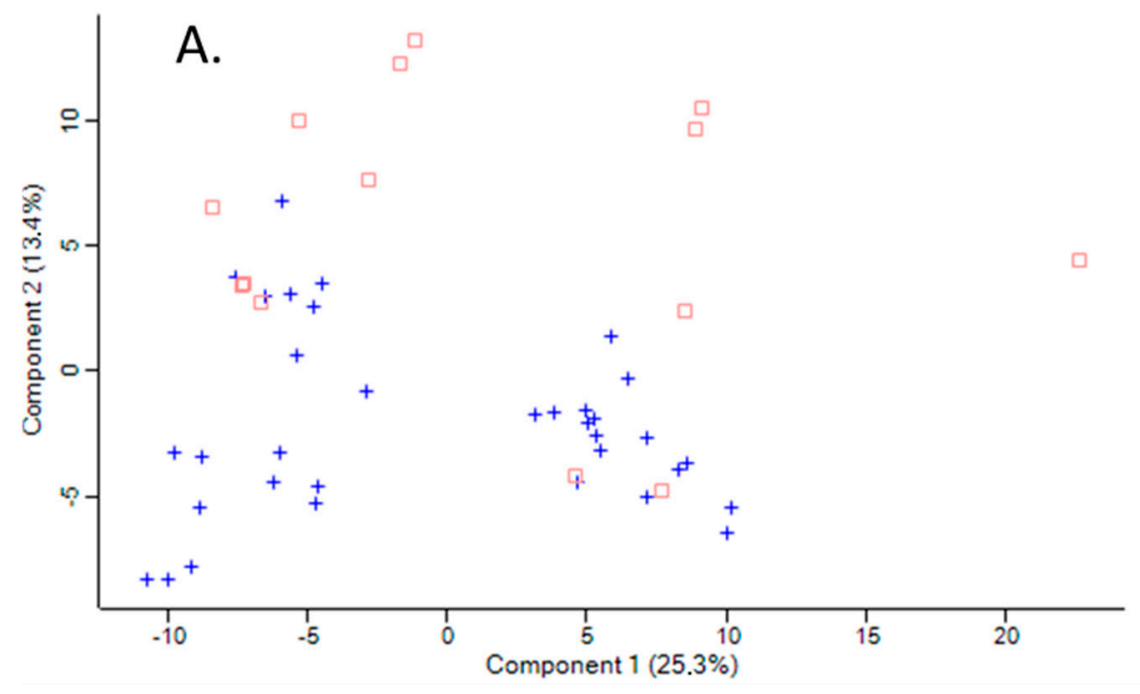

Figure 1. Cont. 


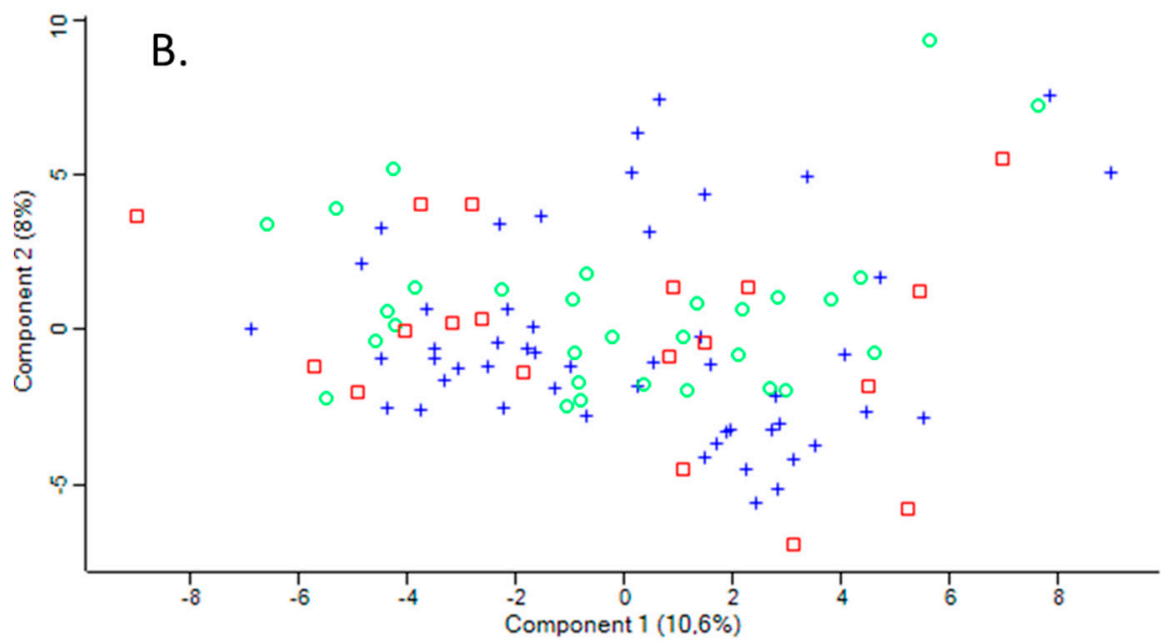

Figure 1. Principal component analysis of the LFQ intensities for plasma proteins. (A). Mice: Pon1 ${ }^{-1-}(n$ = 17; blue cross) and Pon $1^{+/+}$siblings ( $n=8$; red square). (B). Humans: PON1-192QQ ( $n=51$; blue cross), PON1-192QR ( $n=30$; green circle), and PON1-192RR humans $(n=19 ;$ red square). Calculations were performed with Perseus.

We identified 50 differentiating proteins affected by the Pon $1^{-/}$genotype in mice and 21 differentiating proteins affected by the PON1-Q192R polymorphism in humans (Figure 2). Of these, 41 proteins $(84 \%)$ were affected only in mice, while 12 proteins $(57 \%)$ were affected only in humans. There were nine proteins, accounting for $43 \%$ and $22 \%$ of the differentiating proteins in humans and mice, respectively, that were affected by the PON1 genotype in both species (Figure 2). The differentiating proteins and their functions are listed in Supplementary Table S2.

\section{Pon1\% PON1-Q192R \\ mice $(n=50) \quad$ humans $(n=20)$}

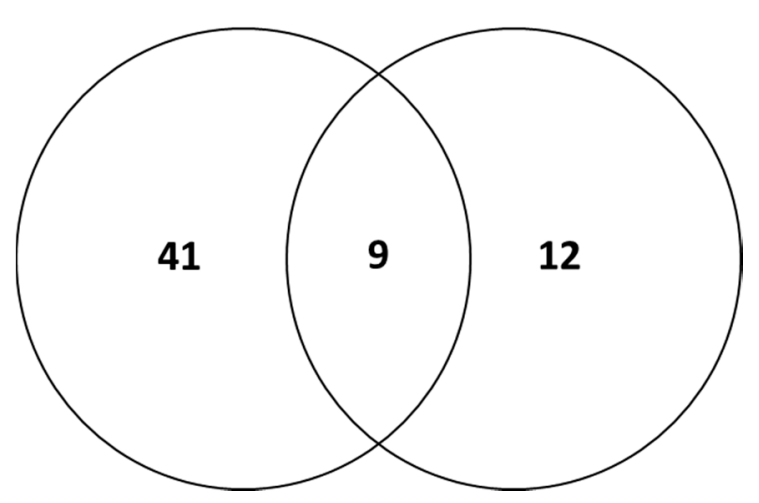

Figure 2. Venn diagram illustrating a partial overlap between proteins affected by PON1 genotype in humans and mice.

\subsection{Plasma Proteins Affected by Pon1 Genotype in Mice}

Of the 50 proteins differentiating between Pon $1^{-/-}$and Pon $1^{+/+}$mice, $31(62 \%)$ were significantly upregulated (from 1.11-fold for prothrombin F2 to 4.50-fold for haptoglobin HP) and 20 (40\%) were downregulated (from 0.02-fold for Pon1 and 0.030-fold for bisphospoglycerate mutase Bpgm to 0.90 -fold for inter- $\alpha$-trypsin inhibitor chain H1, Itih1) (Supplementary Table S2). The majority of proteins affected by the mouse Pon $1^{-/-}$genotype are involved in the immune response $(n=19,38 \%$; immunoglobulins Igk, Ighm, Igj, and Igl), lipoprotein metabolism $(n=7,14 \%$; ApoA1, ApoB, ApoC1, ApoD, ApoM, Lcat, Pon1), complement/coagulation cascades ( $n=8,16 \%$; Al182371, Cfh, Clu, F2, Fetub, 
Klkb1, Mbl1, Serpinc1), blood coagulation ( $n=3,6 \%$; Hrg, Itih1, F13b), and acute phase response $(n=4,8 \%$; Ambp, Hp, Hpx, Ttr) (Figure 3A, Table 2$)$. Other proteins $(n=9 ; 18 \%)$ are involved in glucose/energy metabolism ( $n=3$; Bpgm, Aldoa, Ldha) and other processes $(n=6)$.

A. Mouse Pon $1^{-/-}$

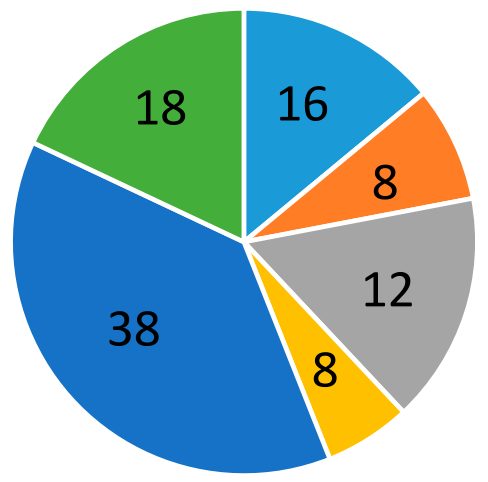

- Lipoprotein metabolism

- Acute phase response

- Complement/coagulation cascades

- Blood coagulation

- Immune response

Other

\section{B. Human PON1-Q192R}

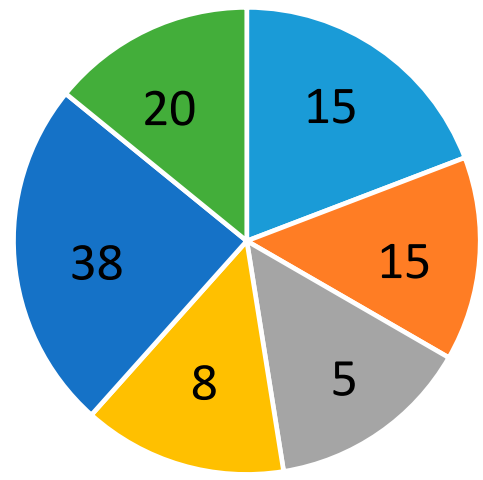

- Lipoprotein metabolism

- Acute phase response

- Complement/coagulation cascades

- Blood coagulation

- Immune response

- Other

Figure 3. Relative numbers of proteins (\%) involved in the indicated molecular processes affected in Pon1 ${ }^{-1-}$ mice (A) and PON1-Q192R humans (B).

Table 2. Proteins affected by PON1 genotype in mice and humans *.

\begin{tabular}{|c|c|c|c|}
\hline \multicolumn{2}{|c|}{ Unique to Mice $(n=41)^{\$}$} & \multirow{2}{*}{$\begin{array}{c}\text { Unique to Humans }(n=12)^{\$} \\
\uparrow \text { GPX3 }\end{array}$} & \multirow[t]{2}{*}{$\begin{array}{c}\text { Proteins Affected in Mice and } \\
\text { Humans }(n=9) \#\end{array}$} \\
\hline$\downarrow$ Blvrb & $\downarrow$ Ldha & & \\
\hline$\downarrow$ Bpgm & $\downarrow$ Lifr & $\downarrow R B P 4$ & \\
\hline$\downarrow$ Aldoa & $\uparrow$ Mug1 & & \\
\hline \multicolumn{2}{|c|}{$\begin{array}{c}\text { Lipoprotein metabolism }(n=3) \text { : } \\
\uparrow \text { ApoB }, \downarrow \text { ApoC1, } \uparrow \text { Lcat }\end{array}$} & & $\begin{array}{l}\text { Lipoprotein metabolism }(n=3): \\
\downarrow \text { APOA } 1 \downarrow, \uparrow A P O D \uparrow, \uparrow \text { APOM } \uparrow, \\
\downarrow P O N 1 \downarrow\end{array}$ \\
\hline \multicolumn{2}{|c|}{$\begin{array}{l}\text { Acute phase response }(n=2) \text { : } \\
\uparrow A m b p, \uparrow \mathrm{Hpx}\end{array}$} & $\begin{array}{l}\text { Acute phase response } \\
\quad(n=1): \uparrow I T I H 3\end{array}$ & $\begin{array}{l}\text { Acute phase response } \\
(n=2): \uparrow H P \downarrow, \uparrow T R R \downarrow\end{array}$ \\
\hline \multicolumn{2}{|c|}{$\begin{array}{c}\text { Blood coagulation }(n=2) \text { : } \\
\uparrow \mathrm{Hrg}, \downarrow \text { Itih1 }\end{array}$} & $\begin{array}{l}\text { Blood coagulation }(n=3): \\
\downarrow \text { PLG, } \downarrow \text { SERPINA10, } \downarrow \text { VTN }\end{array}$ & $\begin{array}{l}\text { Blood coagulation }(n=1) \text { : } \\
\qquad \downarrow \text { F13B } \downarrow\end{array}$ \\
\hline \multicolumn{2}{|c|}{$\begin{array}{c}\text { Complement/coagulation }(n=7): \uparrow \text { Al182371, } \\
\uparrow \text { Cfh, } \uparrow \text { Clu, } \uparrow \mathbf{F} 2, \downarrow \text { Klkb1, } \downarrow \text { Mbl1; } \downarrow \text { Serpinc1 }\end{array}$} & $\begin{array}{l}\text { Complement/coagulation } \\
(n=2): \uparrow C 9, \uparrow V 2-17 \text { (IGL) }\end{array}$ & $\begin{array}{l}\text { Complement/coagulation } \\
\quad(n=1): \uparrow \text { FETUB } \downarrow\end{array}$ \\
\hline $\begin{array}{r}\text { Immune response }(\mathrm{n}=18): \\
\uparrow \uparrow \operatorname{Igk}(n=6), \uparrow \operatorname{Ig}]\end{array}$ & $=9), \uparrow I g j$ & $\begin{array}{c}\text { Immune response }(n=5): \\
\uparrow C F P, \\
\downarrow N / A, \uparrow P G L Y R P 2, \uparrow V 2-6 \\
\text { (IGL), }\end{array}$ & $\begin{array}{c}\text { Immune response }(n=1) \text { : } \\
\downarrow \downarrow \text { IGHG3 } \uparrow\end{array}$ \\
\hline
\end{tabular}

* Proteins highlighted in bold are associated with stroke subtypes in humans (Sikora et al., 2019). ${ }^{\$}$ Up and down arrows indicate the direction of change in protein levels. "Arrows left and right to the protein acronym refer to the change in protein levels in mice and humans, respectively. 


\subsection{Plasma Proteins Affected by PON1-Q192R Polymorphism in Humans}

Among the 21 proteins affected by the PON1-Q192R polymorphism in humans, five were significantly upregulated (from 1.08-fold for $N$-acetyl-muramoyl-L-alanine amidase PGLYRP2 to 1.32-fold for properdin CFP) and eight were significantly downregulated (from 0.62- for PON1 to 0.95-fold for plasminogen PLG) by the PON1-192QQ genotype, compared with PON1-192QR and/or PON1-192QR+PON1-192RR genotypes (Supplementary Table S2). Two proteins (IGHG3 and ITIH3) were significantly upregulated (1.30- and 1.45-fold, respectively) while four (F13B, SERPINA10, RBP4, PON1) were significantly downregulated (0.60- to 0.90-fold) by PON1-192QQ, compared with the PON1-192RR genotype. Six proteins differentiated between PON1-192QR+PON1-192RR genotypes: four were significantly upregulated (APOD, APOM, GPX3, IGL V2-17) and two (SERPINA10, VTN) were downregulated.

Proteins affected by the human PON1-Q192R polymorphism are involved in lipoprotein metabolism ( $n=4,19 \%$; APOA1, APOD, APOM, PON1), blood coagulation $(n=3,14 \%$; PLG, SERPINA10, F13B) and complement/coagulation cascades ( $n=4,19 \%$; C9, V2-17, VTN, FETUB), acute phase response $(n=3,14 \%$; ITIH3, HP, TTR), and immune response ( $n=5,24 \%$; immunoglobulins IGL and IGHG3, properdin CFP, $N$-acetyl-muramoyl-L-alanine amidase PGLYRP2, and vitronectin VTN) (Figure 3B, Table 2). Other proteins $(n=2,10 \%)$ are involved in redox defense (GPX3) and cardiac muscle development (RBP4).

\subsection{Overlap between Proteins Affected by PON1 Genotype in Humans and Mice}

We identified nine proteins whose levels were affected both by the PON1-Q192R polymorphism in humans and the Pon $1^{-/-}$genotype in mice (Figure 2, Table 2). The nine shared proteins represented $43 \%$ and $18 \%$ of the total number of proteins affected by PON1 genotype in humans and mice, respectively. Of those common proteins, five were affected in the same direction in humans and mice (i.e., were either upregulated (APOD, APOM) or downregulated (APOA1, F13B, PON1) in both species). Four other proteins were affected in a different direction in humans and mice: FETUB, HP, and TTR were downregulated in humans and upregulated in mice, while IGHG3 was upregulated in humans and downregulated in mice.

\subsection{Bioinformatics Analysis}

To identify biological pathways linked to proteins affected by the PON1 genotype in humans and mice, bioinformatics analysis with IPA resources was carried out. We found that proteins affected by the human PON1-Q192R polymorphism were significantly enriched in 11 canonical pathways, which are linked to atherosclerosis, thrombosis, and Alzheimer's disease (Figure 4). Proteins in 10 of those pathways were also significantly enriched in Pon1 $1^{-/-}$mice.

Overall, enrichment ratios were higher in Pon1 ${ }^{-/}$mice than in PON1-192QQ humans. The coagulation system, FXR/RXR, LXR/RXR activation, and atherosclerosis signaling pathways had the highest enrichment ratio in Pon $1^{-/-}$mice $(0.114,0.095,0.091$, and 0.064 , respectively; $-\log (p$-value) $=6.7,18.6,16.6$, and 10.9, respectively), about threefold higher than in PON1-192QQ humans (0.029, 0.040, 0.033, and 0.016, respectively: $-\log (p$-value $)=1.9,9.2,7.0$, and 3.0, respectively) (Figure 4), except for the complement system pathway, which had a similar enrichment ratio in Pon1 $1^{-1-}$ mice and in PON1-192QQ humans $(0.027 ;-\log (p$-value $)=1.27$ and 1.84 , respectively $)$.

One canonical pathway, "Neuroprotective Role of THOP1 in Alzheimer's Disease", was marginally significantly enriched in humans $(-\log (p$-value $)=1.35 ; p=0.045)$ but not in mice $(-\log (p$-value $)=0.796$; $p=0.160$ ) (Figure 4).

Fifteen other pathways contained proteins significantly enriched only in $P o n 1^{-/-}$mice and affected glucose/energy metabolism, iron homeostasis, and immune system. 

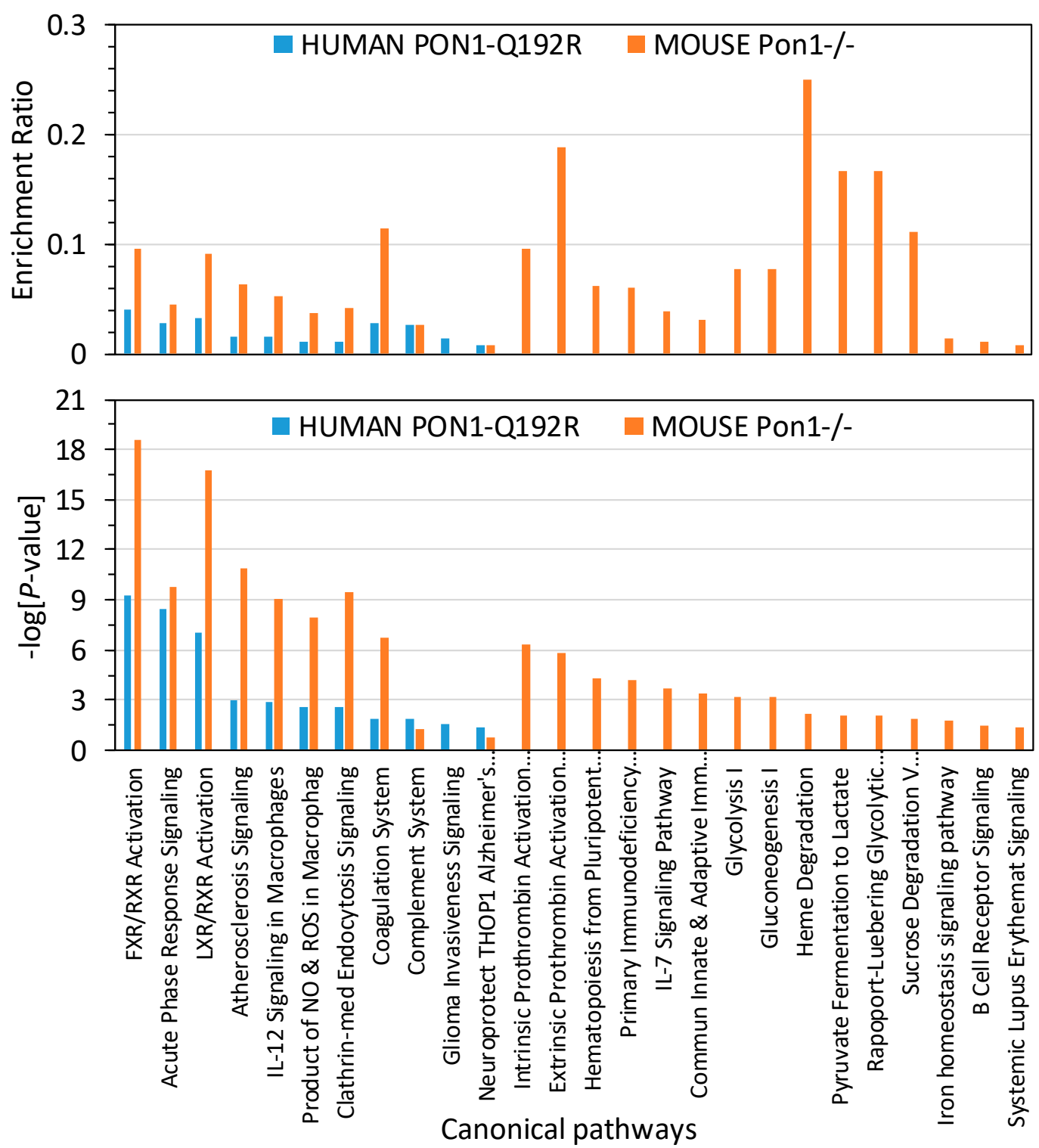

Figure 4. Enrichment ratios and canonical pathways of differentially expressed proteins in PON1-192QQ vs. PON1-192RR+QR humans and $P o n 1^{-/-}$vs. Pon $1^{+/+}$mice identified by IPA. Benjamini-Hochberg, Benferroni, and false discovery rate corrections were applied to minimize the number of false positives.

\subsection{Human PON1-Q192R Polymorphism}

IPA identified two top-scoring biological networks associated with human PON1-Q192R polymorphism: "Lipid Metabolism, Molecular Transport, Small Molecule Biochemistry" and “Cardiovascular Disease, Neurological Disease, Organismal Injury and Abnormalities" (Table 3). 
Table 3. Top molecular networks associated with human PON1-Q192R polymorphism. Upregulated $(\uparrow)$ and downregulated $(\downarrow)$ proteins are highlighted in bold red and green, respectively. Graphical illustrations of interactions between proteins in these networks are shown in Figure 5.

\begin{tabular}{|c|c|c|c|c|}
\hline Analysis & Molecules in Network & Score & $\begin{array}{c}\text { Focus } \\
\text { Molecules }\end{array}$ & $\begin{array}{l}\text { Top Diseases and } \\
\text { Functions }\end{array}$ \\
\hline $\begin{array}{c}P O N 1-192 Q Q \\
\text { vs. } Q R+R R \\
\text { (Figure 5A) }\end{array}$ & $\begin{array}{c}\text { 15-hydroxyeicosatetraenoic acid, } \\
\text { 7-ketocholesterol, AMBP, APOA2, ascorbic } \\
\text { acid, } \uparrow \text { C9, CD68, } \uparrow \text { CFP, Cu2, Fe2, } \downarrow \text { FETUB, } \\
\text { FOS, GHRL, HDL, IL6, Immunoglobulin, } \\
\text { ITIH1, } \uparrow I T I H 3, \text { ITIH4, L-phenylalanine, LCAT, } \\
\text { LDL, lipid peroxide, MSR1, palmitoleic acid, } \\
\uparrow \text { PGLYRP2, } \downarrow \text { PLG, PLTP, } \downarrow \text { PON1, PON3, Rbp, } \\
\downarrow \text { RBP4, TGFB1, } \downarrow T T R, \text { VLDL-cholesterol }\end{array}$ & 27 & 9 & $\begin{array}{c}\text { Lipid Metabolism, } \\
\text { Molecular } \\
\text { Transport, Small } \\
\text { Molecule } \\
\text { Biochemistry }\end{array}$ \\
\hline $\begin{array}{l}P O N 1-192 Q Q \\
\text { vs. } Q R\end{array}$ & $\begin{array}{c}\text { 15-hydroxyeicosatetraenoic acid, APCS, } \\
\downarrow \text { APOA1, Apoc1, APOF, APOL1, } \downarrow \text { APOM, } \\
\text { bilirubin, } \uparrow \text { C9, } \uparrow \text { CFP, Cxcl9, Fe2, Ferritin, } \\
\downarrow \text { GPX3, Growth hormone, GSTT1, } \downarrow \text { HBB, HBD, } \\
\text { HBG1, HBQ1, HDL, hemoglobin, } \downarrow \text { HPR, } \\
\text { Immunoglobulin, Insulin, ITIH4, LDL, } \downarrow \text { PON1, } \\
\text { PON3, Rbp, } \downarrow \text { RBP4, SAA2, SELENOT, } \downarrow \text { TTR, } \\
\text { IGHV1-69, } \uparrow \text { IGLV3-9 }\end{array}$ & 28 & 11 & $\begin{array}{c}\text { Lipid Metabolism, } \\
\text { Molecular } \\
\text { Transport, Small } \\
\text { Molecule } \\
\text { Biochemistry }\end{array}$ \\
\hline $\begin{array}{l}\text { PON1-192QQ } \\
\text { vs. RR }\end{array}$ & $\begin{array}{c}\text { 15-hydroxyeicosatetraenoic acid, AFM, Alpha } 1 \\
\text { antitripsin, AMBP, C1QTNF3, CCR2, CD40LG, } \\
\text { Cd64, CD68, CXADR, } \downarrow \text { F13B, FCGR2C, Fe2, } \\
\text { IFNG, IgG3 kappa, IgG3 lambda, IGHG1, } \\
\uparrow \text { IGHG3, IGHG4, ITIH1, } \uparrow \text { ITIH3, ITIH4, LCAT, } \\
\text { lipid peroxide, MSR1, MTRR, palmitoleic acid, } \\
\downarrow \text { PON1, PON3, RAD51AP1, } \downarrow R B P 4, \\
\downarrow \text { SERPINA10, TGFB1, TNFAIP6, } \\
\text { VLDL-cholesterol }\end{array}$ & 18 & 6 & $\begin{array}{c}\text { Lipid Metabolism, } \\
\text { Molecular } \\
\text { Transport, Small } \\
\text { Molecule } \\
\text { Biochemistry }\end{array}$ \\
\hline $\begin{array}{c}\text { PON1-192QR } \\
\text { vs. RR } \\
\text { (Figure 5B) }\end{array}$ & $\begin{array}{c}\text { ALCAM, Alpha } 1 \text { antitrypsin, APOA2, APOA4, } \\
\uparrow \text { APOD, Apolipoprotein, } \uparrow \text { APOM, arginine, } \\
\text { C8G, C9, CD40LG, CLCN5, DUX4, F10, } \\
\text { FAM20C, glutathione, glycosaminoglycan, } \\
\text { GPX1, } \uparrow \text { GPX3, HDL, HMOX1, LCAT, LCN, } \\
\text { NFE2L2, NFKBIA, NRG1, POU2F1, SEMA3F, } \\
\downarrow \text { SERPINA10, SERPINC1, SREBF1, sulfatides, } \\
\text { TFRC, UBQLN1, } \downarrow \text { VTN }\end{array}$ & 14 & 5 & $\begin{array}{c}\text { Cardiovascular } \\
\text { Disease, } \\
\text { Neurological } \\
\text { Disease, } \\
\text { Organismal Injury } \\
\text { and Abnormalities }\end{array}$ \\
\hline
\end{tabular}

The "lipid metabolism, molecular transport, small molecule biochemistry" network, identified from analyses $P O N 1-192 Q Q$ vs. $Q R+R R$, had a score of 27 and contained 35 molecules, including 27 proteins. Nine proteins from this network were quantified by label-free mass spectrometry, while 17 proteins and 9 other molecules were identified by IPA to interact with the quantified proteins (Table 3). Graphical illustration of this network is shown in Figure 5A. Proteins in this network participate in lipid metabolism and acute phase/immune response and show strong interactions centering on the lipoproteins LDL and PON1/HDL, the cytokine IL6, and TGFB1. Similar lipid metabolism networks were identified from analyses PON1- PON1-192QQ vs. $Q R$ and PON1-192QQ vs. $R R$ (Table 3), suggesting that this network was associated with $P O N 1-192 Q Q$ polymorphism.

The "cardiovascular disease, neurological disease, organismal injury and abnormalities" network, identified from analysis PON1-192QQ vs. RR, was associated with PON1-192RR polymorphism. The cardiovascular/neurological disease network has a score of 14 and contains 35 molecules, including 31 proteins. Five proteins from this network were quantified by label-free mass spectrometry while 26 proteins and 4 other molecules were identified by IPA to interact with the quantified proteins (Table 3). Proteins of this network participate in oxidative stress response, lipoprotein metabolism, and NF- $\mathrm{KB}$ signaling and show strong interactions centering on the NF- $\mathrm{KB}$ inhibitor alpha NFKBIA and HDL (Figure 5B). 
A.

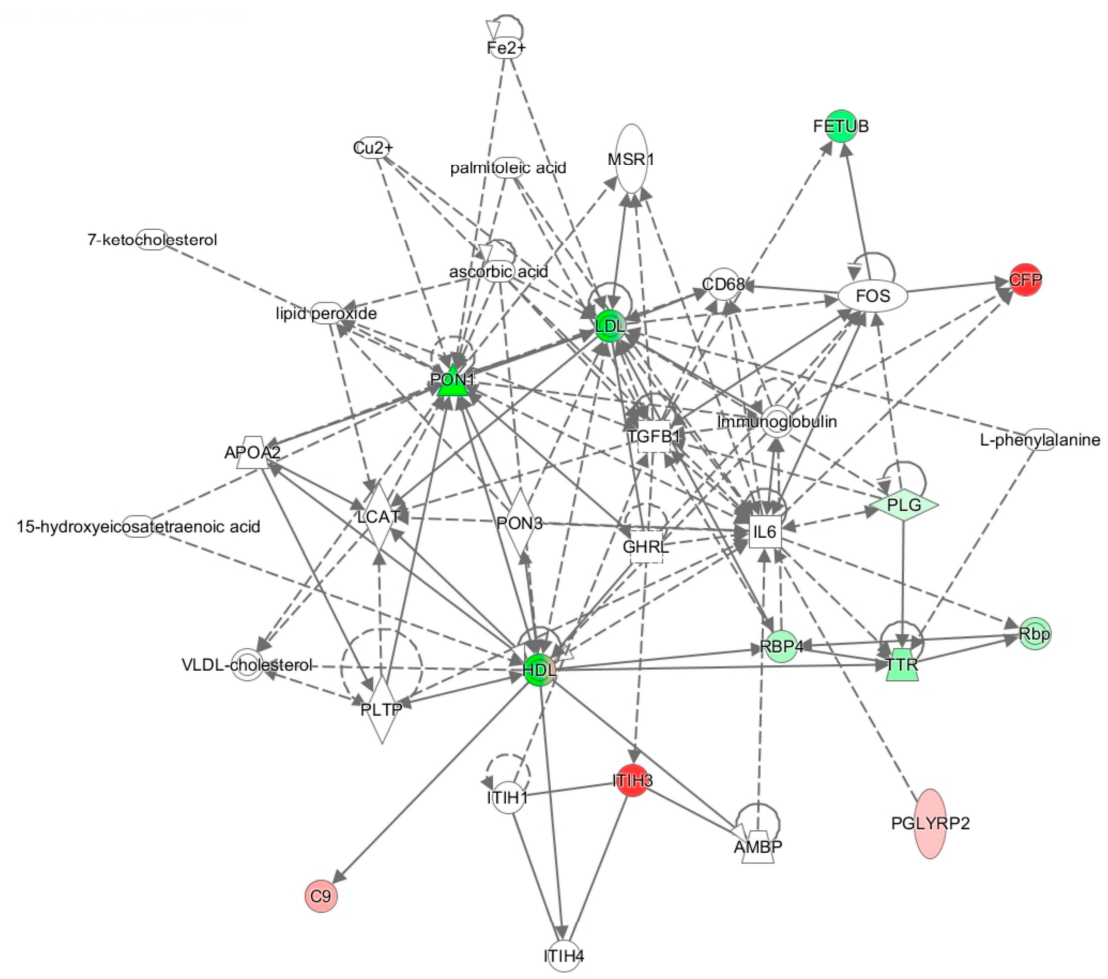

B.

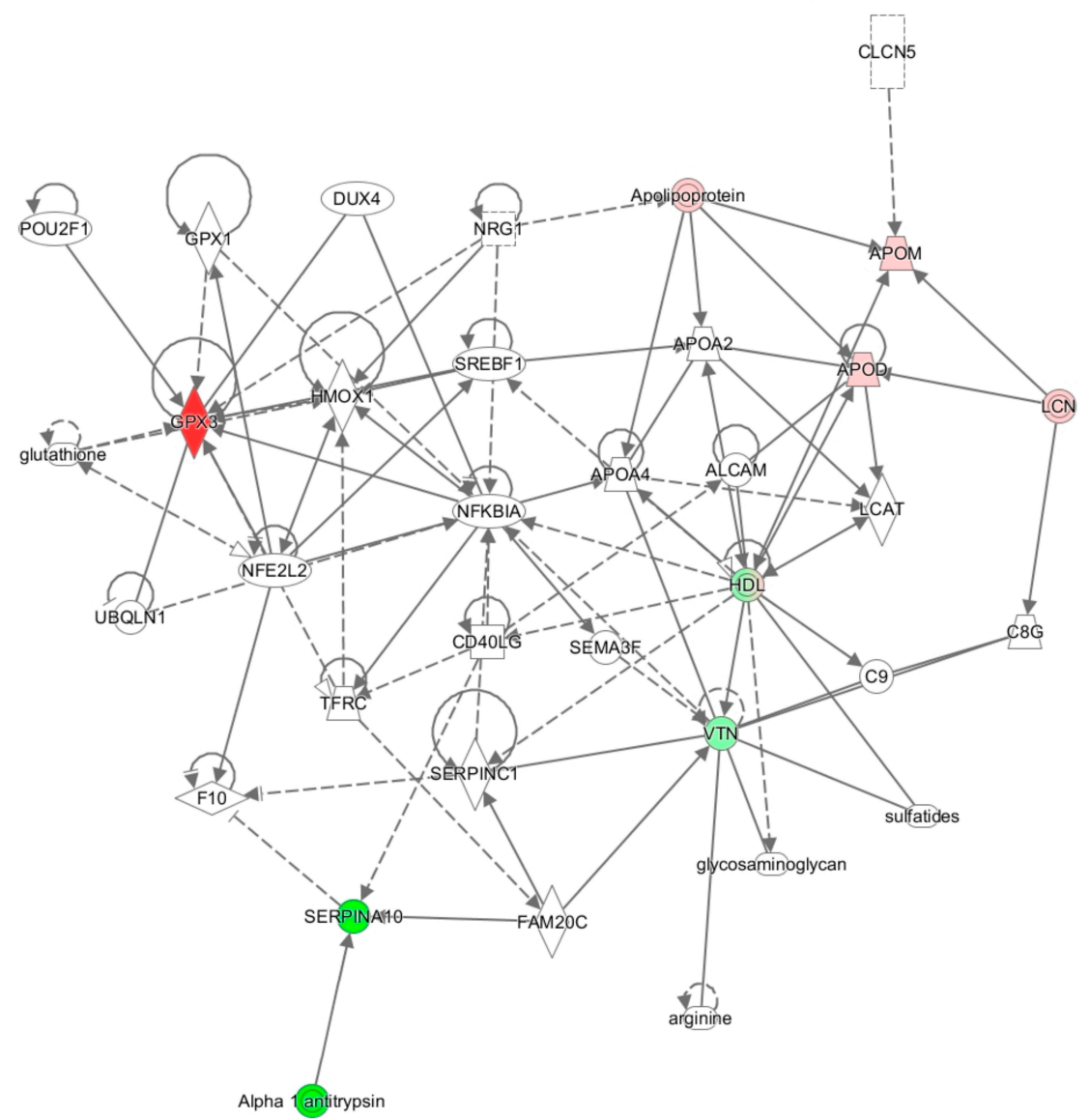

Figure 5. Molecular networks associated with $P O N 1-Q 192 R$ polymorphism in humans. (A) Lipid Metabolism, Molecular Transport, Small Molecule Biochemistry; (B) Cardiovascular Disease, Neurological Disease, Organismal Injury and Abnormalities. Upregulated and downregulated proteins are highlighted in red and green, respectively. 


\subsection{Pon1 $1^{-/}$Mouse Genotype}

IPA identified three top-scoring biological networks associated with mouse Pon $1^{-/-}$genotype (Table 4). The "Lipid Metabolism, Molecular Transport, Small Molecule Biochemistry" network, with a score of 41 , contains 32 proteins. Eighteen of those proteins were quantified by label-free mass spectrometry while 14 were identified by IPA to interact with the quantified proteins. This network involves proteins participating in lipid metabolism, iron metabolism, acute phase response, and complement/coagulation cascades that show strong interactions centering on lipoproteins PON1/APOA1/HDL and APOB/LDL, and ERK1/2 (Figure 6A).

Table 4. Top molecular networks associated with Pon $1^{-/}$genotype in mice. Upregulated ( $\left.\uparrow\right)$ and downregulated $(\downarrow)$ proteins are highlighted in bold red and green, respectively. Graphical illustrations of interactions between proteins in these networks are shown in Figure 6A-C.

\begin{tabular}{|c|c|c|c|c|}
\hline Analysis & Molecules in Network & Score & $\begin{array}{c}\text { Focus } \\
\text { Molecules }\end{array}$ & $\begin{array}{l}\text { Top Diseases and } \\
\text { Functions }\end{array}$ \\
\hline $\begin{array}{c}\text { Pon } 1^{-/-} \\
\text {vs. } \\
\text { Pon } 1^{+/+} \text {Figure } 6 \mathrm{~A}\end{array}$ & $\begin{array}{c}\downarrow \text { ALB }, \uparrow \text { AMBP, } \downarrow \text { APOA1, } \uparrow \text { APOB, } \downarrow \text { Apoc1, } \\
\uparrow \text { APOD, } \uparrow \text { APOM, } \uparrow \text { CFH, chymotrypsin, } \uparrow \text { CLU, } \\
\text { ERK1/2, Ferritin, Fibrinogen, Growth hormone, } \\
\text { HDL, HDL-cholesterol, hemoglobin, } \uparrow \text { HP, } \uparrow \text { HPX, } \\
\downarrow \text { ITIH1, Kallikrein, } \downarrow \text { KLKB1, } \uparrow \text { LCAT, } \downarrow \text { Ldh } \\
\text { (complex), LDL, LDL-cholesterol, MHC Class II } \\
\text { (complex), Nr1h, } \downarrow \text { PON1, PRKAA, } \\
\text { Pro-inflammatory Cytokine, } \downarrow \text { SERPINC1, Tcf } \\
\text { 1/3/4, } \uparrow T T R, \text { VLDL-cholesterol }\end{array}$ & 41 & 17 & $\begin{array}{c}\text { Lipid Metabolism, } \\
\text { Molecular } \\
\text { transport, Small } \\
\text { Molecule } \\
\text { Biochemistry }\end{array}$ \\
\hline $\begin{array}{c}\text { Pon } 1^{-/-} \\
\text {vs. } \\
\text { Pon } 1^{+/+} \text {Figure 6B }\end{array}$ & $\begin{array}{c}\downarrow \text { AFM, Akt, Ap1, } \downarrow \text { BLVRB, } \downarrow \text { BPGM, cytokine, } \\
\text { ERK, F2, GOT, } \downarrow \text { HGFAC, Iga, IgG, IgG1, IgG2a, } \\
\text { IgG2b, Igg3, Igh (family), } \uparrow \text { Igha, IGHG1, } \\
\uparrow \text { IGHM, } \uparrow \text { Iglv1, Igm, IL1, Immunoglobulin, } \\
\text { Insulin, JCHAIN, } \downarrow \text { LIFR, MAP2K1/2, Mapk, } \\
\downarrow \text { Mbl1, NFkB (complex), P38 MAPK, PI3K } \\
\text { (complex), STAT, Tgf beta }\end{array}$ & 26 & 12 & $\begin{array}{c}\text { Humoral Immune } \\
\text { Response, } \\
\text { Inflammatory } \\
\text { Response, Protein } \\
\text { Synthesis }\end{array}$ \\
\hline $\begin{array}{c}\text { Pon } 1^{-/-} \\
\text {vs. } \\
\text { Pon } 1^{+/+} \text {Figure 6C }\end{array}$ & $\begin{array}{c}\downarrow \text { ALDOA, ANGPT2, CASR, CD163, EED, } \downarrow \text { F13B, } \\
\uparrow \text { FETUB, FN1, } \uparrow \text { HP, } \uparrow \text { Hrg, } \uparrow \text { Igha, } \downarrow \text { Ighg3, } \\
\uparrow \text { Ighv3-6, Igkv1-117, Igkv14-111, } \uparrow \text { Igkv17-127, } \\
\text { IL4, Jnk, LDH (family), } \downarrow \text { LDHA, LINC01139, } \\
\text { lipid peroxide, lysophosphatidylinositol, } \\
\text { miR-18a-5p (and other miRNAs w/seed } \\
\text { AAGGUGC), MSR1, Mug1/Mug2, Pkc(s), PKD1, } \\
\text { PLAGL2, pyruvaldehyde, SBNO2, TGFB1, TLL1, } \\
\text { trypsin, Vegf }\end{array}$ & 26 & 12 & $\begin{array}{l}\text { Cell-to-Cell } \\
\text { Signaling and } \\
\text { Interaction, He- } \\
\text { matological System } \\
\text { Development and } \\
\text { Function, Immune } \\
\text { Cell Trafficking }\end{array}$ \\
\hline
\end{tabular}

The "Humoral Immune Response, Inflammatory Response, Protein Synthesis" network with a score of 26 contains 36 proteins. Twelve of those proteins were quantified by label-free mass spectrometry while 25 were identified by IPA to interact with the quantified proteins. This network contains immunoglobulins and other proteins participating in the acute phase/immune response, which show strong interactions centering on ERK, P38/MAPK, Akt, and NF-kB (Figure 6B).

The "Cell-to-Cell Signaling and Interaction, Hematological System Development and Function, Immune Cell Trafficking" network with a score of 26 contains 33 proteins. Twelve of those proteins were quantified by label-free mass spectrometry while 21 were identified by IPA to interact with the quantified proteins. This network involves proteins participating in cell signaling and acute phase/immune response, which show strong interactions centering on Tgfb1, Vegf, Jnk (Figure 6C). 
A.

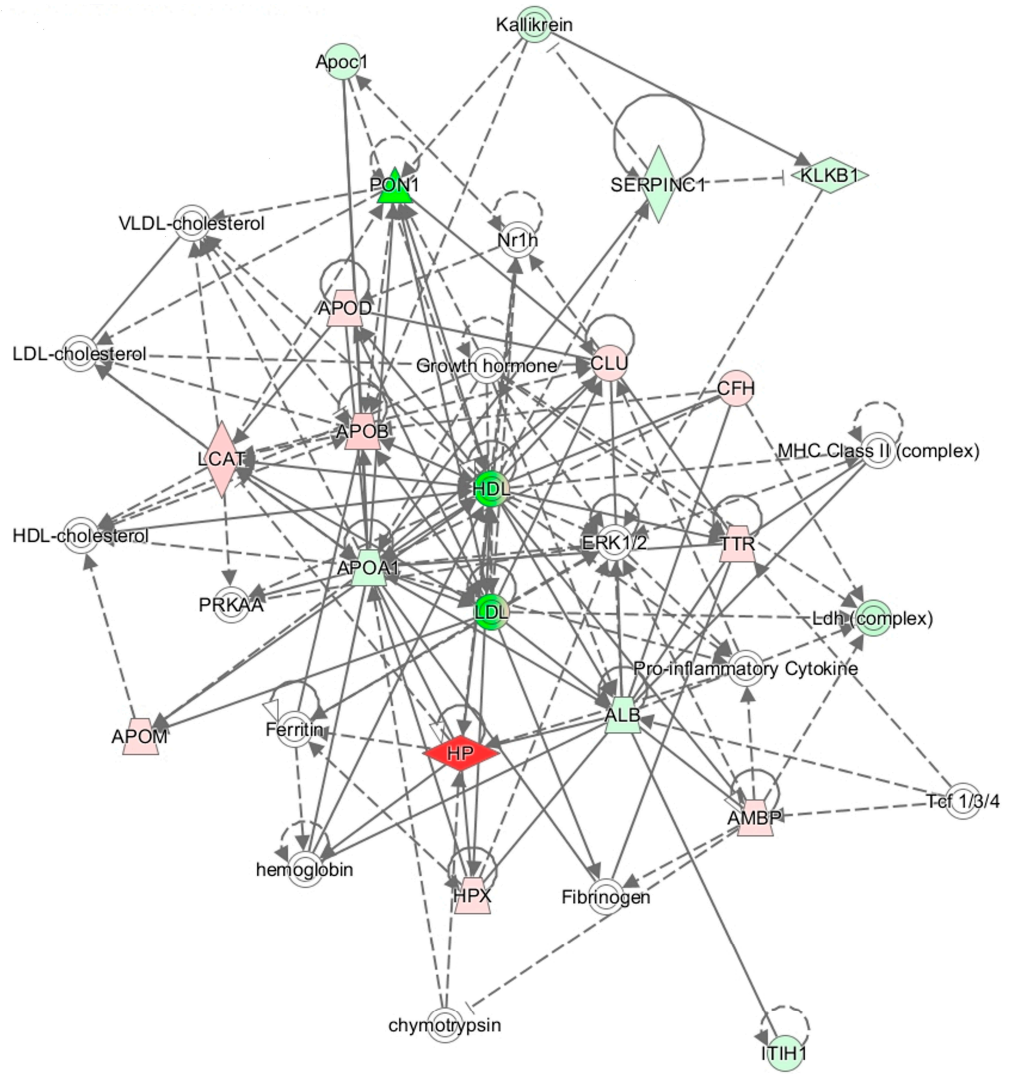

B.

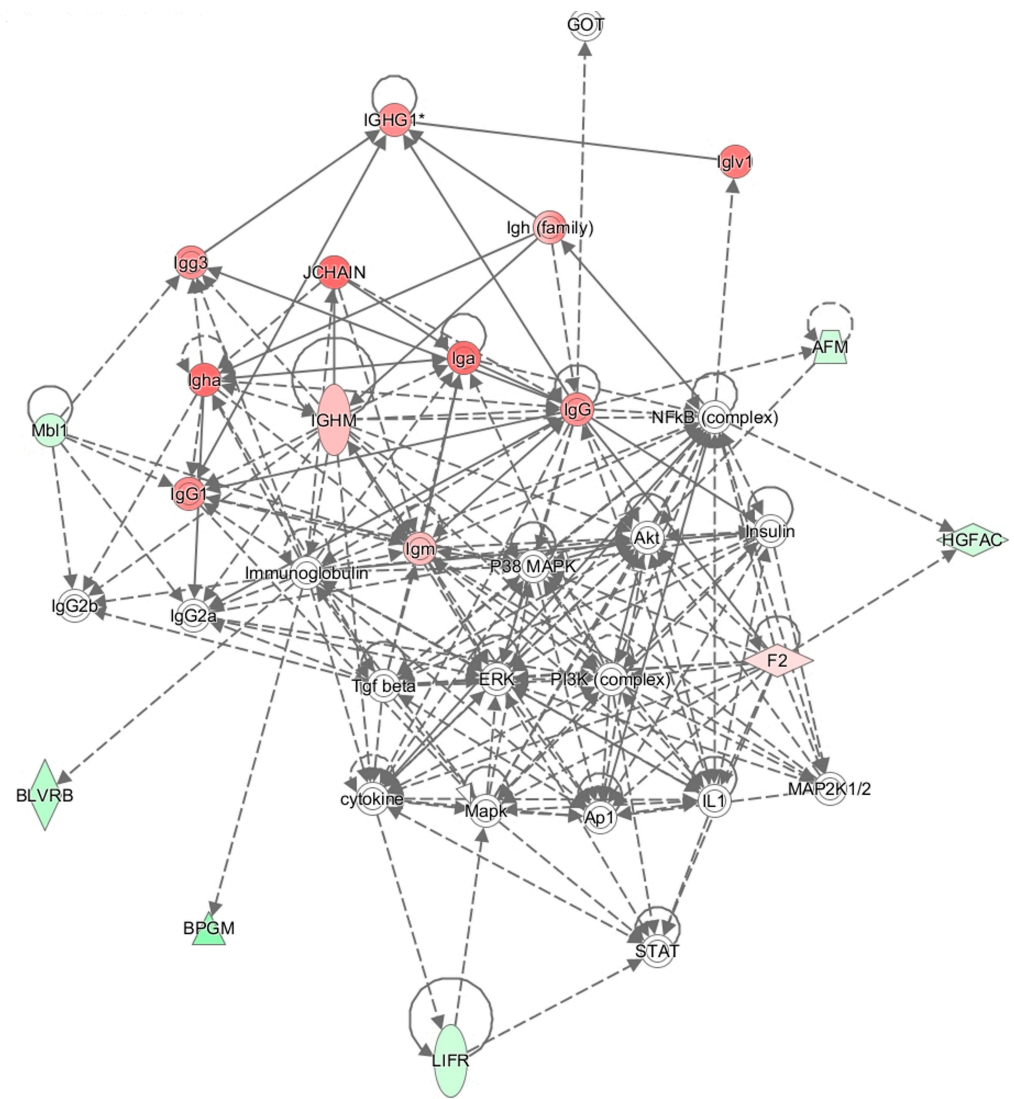

Figure 6. Cont. 
C.

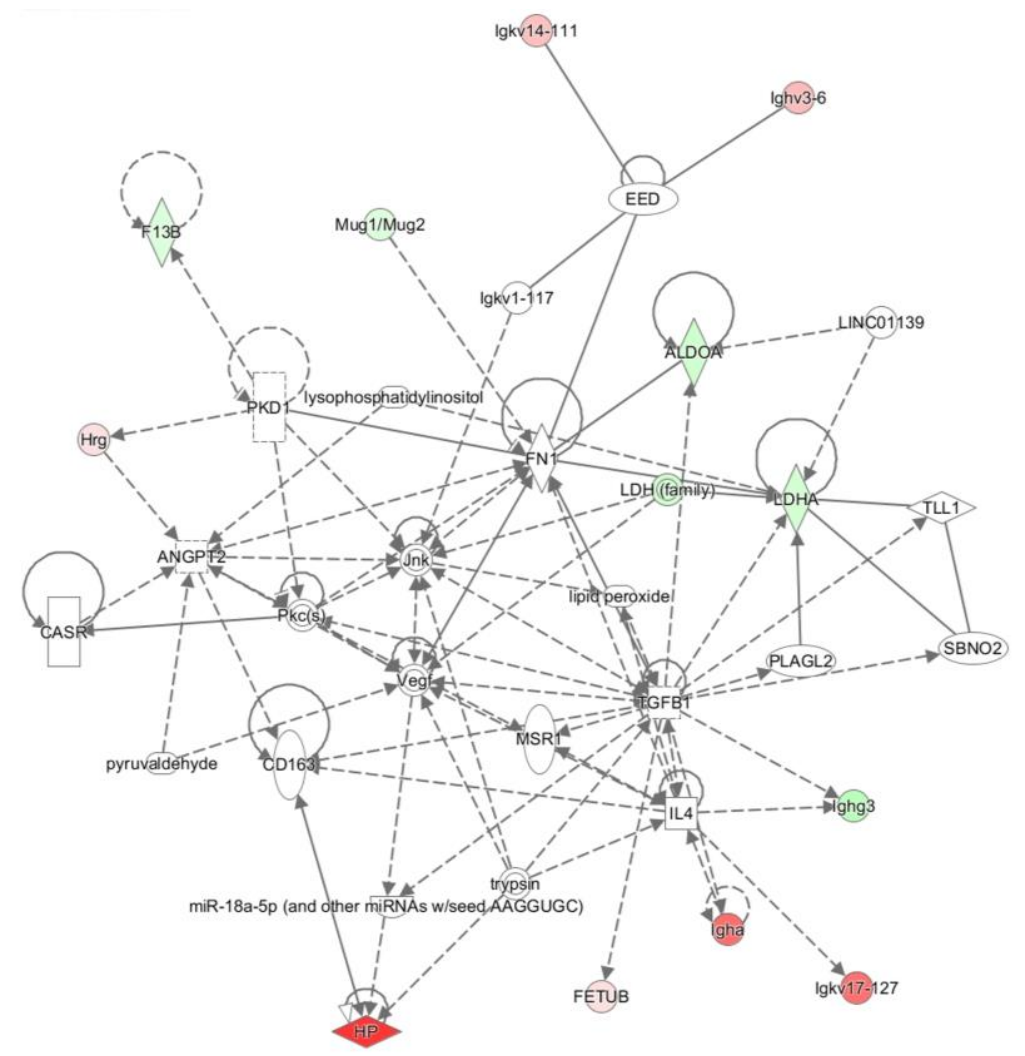

Figure 6. Molecular networks associated with Pon1 ${ }^{-/-}$genotype in mice. (A) Lipid Metabolism, Molecular Transport, Small Molecule Biochemistry. (B) Humoral Immune Response, Inflammatory Response, Protein Synthesis. (C) Cell-to-Cell Signaling and Interaction, Hematological System Development and Function, Immune Cell Trafficking. Upregulated and downregulated proteins are highlighted in red and green, respectively.

\section{Discussion}

The present study provides evidence that genetic reduction of PON1 levels induces proatherogenic changes in plasma proteomes of humans and mice. Specifically, we show for the first time that (i) PON1-Q192R polymorphism in humans and Pon1 $^{-/-}$genotype in mice induce similar changes in the plasma proteome, which affect a major biological network involving proteins participating in lipoprotein metabolism, the "Lpid Metabolism, Molecular Transport, Small Molecule Biochemistry" network; (ii) these genetic variants also induce other changes in plasma proteomes, which are species-specific and affect different biological networks in humans and mice: "Cardiovascular Disease, Neurological Disease, Organismal Injury and Abnormalities" in PON1-192QQ vs. RR humans and "Humoral Immune Response, Inflammatory Response, Protein Synthesis" and "Cell-to-Cell Signaling and Interaction, Hematological System Development and Function, Immune Cell Trafficking" in $P o n 1^{-/-}$vs. Pon $1^{+/+}$mice. Comparative proteomics of the human PON1-Q192R polymorphism and the mouse $P o n 1^{-/-}$genotype have not been examined before, and, to our best knowledge, this is the first study of plasma proteomes in PON1-Q192R humans and Pon1 ${ }^{-/-}$mice. Overall, these changes in plasma proteomes are proatherothrombotic and are known to be associated with human cardiovascular and neurological diseases.

Some of the plasma proteins affected by the PON1 genotype are shared between humans and mice while changes in other proteins are species-specific and limited to humans or mice. The shared proteins include lipoproteins APOD and APOM (negative regulators of lipoprotein oxidation), the carrier of hydrophobic molecules AFM (involved in transport of fatty acids, or vitamin E when the lipoprotein system is insufficient), the negative regulator of endopeptidase activity FETUB, the antioxidant HP 
(involved in acute inflammatory response), the thyroid hormone-binding protein TTR (involved in thyroxine transport from the blood to the brain), the fibrin-stabilizing factor F13B (associated with a risk of stroke), and the immunoglobulin IGHG3 (involves B-cell signaling, complement activation, and humoral immunity). The species-specific proteins affected by the PON1 genotype are more numerous in mice $(n=41)$ than in humans $(n=12)$ and most likely reflect a much more severe effect of the Pon 1 gene deletion on Pon 1 function (essentially complete absence of both Pon1 protein and activity) in mice $[6,13,22]$ than the effect of PON1-Q192R polymorphism on PON1 function in humans (about $40 \%$ reduction in PON1 protein and 10-fold in PON1 activity).

Our findings in PON1-Q192R humans and Pon1 ${ }^{-1-}$ mice can explain the cardiovascular and neurological pathologies associated with the variation in PON1 genotypes in the two species. Specifically, identification of $P O N 1$ genotype-responsive proteins involved in lipid/cholesterol metabolism/transport (APOD, APOM in humans; ApoA1, ApoB, ApoC1, ApoD, ApoM in mice), acute phase response (HP, ITIH3, TTR in humans; Ambp, Hpx, Hp, Ttr in mice), and complement/coagulation (C9, PLG, SERPINA10 in humans; Cfh, F2, Klkb1, Mbl1, Serpinc1, Itih1 in mice) provides support for this conclusion.

We found that the lipoproteins APOD and APOM were upregulated by PON1-192QR vs. PON1-192RR genotype in humans and Pon1 ${ }^{-/-}$genotype in mice. Elevation in APOD expression has been associated with a number of pathological conditions including neurodegenerative disease [26]. Both APOD and APOM are negative regulators of lipoprotein oxidation and have antiatherogenic properties. ApoD is an acute response protein with a protective function mediated by the control of peroxidized lipids. In mice, deletion of the $A p o D$ gene increases the sensitivity to oxidative stress, levels of lipid peroxides in the brain, and impairs learning and locomotor abilities [26]. APOM binds oxidized phospholipids in plasma and increases the antioxidant effect of HDL [27]. Thus, changes in APOD and APOM levels could contribute to the association of the PON1 genotype with cardiovascular and neurological diseases.

In the present study we found that ApoA1 and $\mathrm{ApoC} 1$, known to be negative regulators of lipid/cholesterol catabolism/transport cholesterol, were downregulated, while ApoB, a positive regulator of lipid/cholesterol storage, was upregulated in Pon $1^{-/-}$mice. These findings suggest that the Pon $1^{-/-}$genotype exerts a proatherogenic effect on the lipoprotein homeostasis.

We identified several proteins of the coagulation system that were affected by the PON1 genotype. For example, PLG, SERPINA10, and F13B were downregulated by the PON1-192QQ genotype in humans. PLG, bound to fibrin clots, is converted to plasmin, which plays a crucial role in dissolving blood clots. SERPINA1, a negative regulator of blood coagulation, inhibits the activated coagulation factors $\mathrm{X}$ and $\mathrm{XI}$, thus preventing fibrin clot formation [28]. F13B is a subunit of prototransglutaminase, which is activated at the final stage of coagulation and which stabilizes the clot by forming an amide bond between Glu and Lys residues of fibrin [29]. A genetic variant of F13B is associated with the risk of stroke [30]. Thus, reduced levels of PLG, SERPINA10, and F13B in carriers of PON1-192QQ genotype suggest that the 192QQ variant could increase the propensity to atherothrombosis, which might account for an association of this variant with vascular disease [16,31].

The antithrombin Serpinc1, a component of the complement/coagulation cascades, was downregulated in Pon $1^{-/-}$mice. As genetic variants of SERPINC1 are known to be associated with venous thrombosis in humans [32], the downregulation of the antithrombin Serpinc1 in Pon1 $1^{-/}$mice could increase thrombin activity, thereby increasing blood clotting, which might account for increased atherosclerotic lesions observed in these animals when fed with a high-fat diet [13].

Proteins affected by PON1-Q192R polymorphism in humans and Pon1-- genotype in mice were also significantly enriched in the LXR/RXR activation pathway, which can also affect blood homeostasis (Figure 4). RXR is a negative regulator of platelet function/aggregation and thrombus formation [33]. Thus, proteins of the LXR/RXR pathway that we found to be affected by the PON1-Q192R polymorphism in humans (C9, FETUB, HP, PON1, RBP4, TTR, APOM) and Pon1 ${ }^{-/-}$genotype in mice (Alb, Ambp, 
ApoA1, ApoB, ApoD, ApoM, Clu, FetuB, Hpx, Lcat, Pon1, Ttr) can contribute to the cardiovascular phenotype associated with the PON1 genotype.

We also found that the PON1 genotype affected proteins of the Il-7 signaling pathway. IL-7 activates JAK-STAT, PI-3 kinase, and Src kinase pathways, which is important in the development/proliferation of the immune $\mathrm{B}$ and $\mathrm{T}$ cells in mice and $\mathrm{T}$ cells in humans. Pon $1^{-/-}$mice showed significantly upregulated expression of immunoglobulins such as Igha, Ighm, Ighg (1, 3), Ighv (1-76, 3-6, 7-1, 10-1), and Igkv (4-63, 8-28, 17-127, 19-93) (Table 2, Supplementary Table S2). PON1-192QQ humans also showed upregulated expression, although to a more limited extent than $P o n 1^{-/-}$mice, with only two immunoglobulins upregulated, IGHG3 and IGLV2-17. These findings suggest genetic attenuation of PON1 activity leads to enhanced immune response due to increased Il-7/B-cell signaling.

\section{Conclusions}

Our findings identify a proatherogenic phenotype in the plasma proteome associated with the PON1 genotype in humans and mice. This phenotype includes mild dysregulation of lipoproteins but is silent, even in Pon $1^{-/}$mice. However, it can be exacerbated by a stress such as severe dyslipidemia induced by a proatherogenic high-fat diet. Indeed, Pon1 $1^{-/}$mice became susceptible to aortic lesions only when fed with a high-fat diet but not a standard chow diet [13]. Other metabolic stressors, such as elevated Hcy, have been found to modulate expression of brain proteins involved in oxidative stress and neurodegeneration in Pon $1^{-/-}$mice [34].

Supplementary Materials: The following are available online at http:/www.mdpi.com/2076-3921/9/12/1198/s1, Table S1: Characteristics of participants, Table S2: PON1 genotype-responsive proteins in humans and mice.

Author Contributions: M.S. carried out mass spectrometry experiments and analyzed the data; Ł.M. contributed to mass spectrometry experiments; E.B. determined PON1 genotypes, J.P.-K. quantified PON1 activities, I.L. determined Pon 1 genotypes. H.J. bred the mice, collected blood/plasma samples, and quantified Pon1 activities, designed the study, analyzed the results, wrote the manuscript, and had the responsibility for the final content. All authors have read and approved the final version of the manuscript.

Funding: Supported in part by grants from the National Science Center, Poland (2015/17/D/NZ5/03444, 2016/23/B/NZ5/00573, 2018/29/B/NZ4/00771，2019/33/B/NZ4/01760), and the American Heart Association (17GRNT32910002).

Conflicts of Interest: The authors declare no competing interests.

\section{References}

1. Lewington, S.; Whitlock, G.; Clarke, R.; Sherliker, P.; Emberson, J.; Halsey, J.; Qizilbash, N.; Peto, R.; Collins, R. Blood cholesterol and vascular mortality by age, sex, and blood pressure: A meta-analysis of individual data from 61 prospective studies with 55000 vascular deaths. Lancet 2007, 370, 1829-1839.

2. Mackness, M.; Mackness, B. Paraoxonase 1 and atherosclerosis: Is the gene or the protein more important? Free. Radic. Biol. Med. 2004, 37, 1317-1323. [CrossRef] [PubMed]

3. Durrington, P.N.; Mackness, B.; Mackness, M.I. Paraoxonase and Atherosclerosis. Arter. Thromb. Vasc. Biol. 2001, 21, 473480. [CrossRef] [PubMed]

4. Costa, L.G.; Cole, T.B.; Jarvik, G.P.; Furlong, C.E. Functional genomic of the paraoxonase (PON1) polymorphisms: Effects on pesticide sensitivity, cardiovascular disease, and drug metabolism. Annu. Rev. Med. 2003, 54, 371-392. [CrossRef] [PubMed]

5. Loscalzo, J. Paraoxonase and coronary heart disease risk: Language misleads, linkage misinforms, function clarifies. Circ. Cardiovasc Genet. 2008, 1, 79-80. [CrossRef]

6. Jakubowski, H. Calcium-dependent Human Serum Homocysteine Thiolactone Hydrolase. J. Biol. Chem. 2000, 275, 3957-3962. [CrossRef]

7. Jakubowski, H. Homocysteine Modification in Protein Structure/Function and Human Disease. Physiol. Rev. 2019, 99, 555-604. [CrossRef]

8. Borowczyk, K.; Piechocka, J.; Głowacki, R.; Dhar, I.; Midtun, Ø.; Tell, G.S.; Ueland, P.M.; Nygård, O.; Jakubowski, $\mathrm{H}$. Urinary excretion of homocysteine thiolactone and the risk of acute myocardial infarction in coronary artery disease patients: The WENBIT trial. J. Intern. Med. 2019, 285, 232-244. [CrossRef] 
9. Perla-Kajan, J.; Borowczyk, K.; Glowacki, R.; Nygard, O.; Jakubowski, H. Paraoxonase 1 Q192R genotype and activity affect homocysteine thiolactone levels in humans. FASEB J. Off. Publ. Fed. Am. Soc. Exp. Biol. 2018, 32, 6019-6024.

10. Lacinski, M.; Skorupski, W.; Cieslinski, A.; Sokolowska, J.; Trzeciak, W.H.; Jakubowski, H. Determinants of homocysteine-thiolactonase activity of the paraoxonase-1 (PON1) protein in humans. Cell. Mol. Biol. 2004, 50, 885-893.

11. Jakubowski, H.; Ambrosius, W.T.; Pratt, J. Genetic determinants of homocysteine thiolactonase activity in humans: Implications for atherosclerosis. FEBS Lett. 2001, 491, 35-39. [CrossRef]

12. Mackness, M.; Mackness, B. Human paraoxonase-1 (PON1): Gene structure and expression, promiscuous activities and multiple physiological roles. Gene 2015, 567, 12-21. [CrossRef] [PubMed]

13. Shih, D.M.; Gu, L.; Xia, Y.-R.; Navab, M.; Li, W.-F.; Hama, S.; Castellani, L.W.; Furlong, C.E.; Costa, L.G.; Fogelman, A.M.; et al. Mice lacking serum paraoxonase are susceptible to organophosphate toxicity and atherosclerosis. Nat. Cell Biol. 1998, 394, 284-287. [CrossRef] [PubMed]

14. Shih, D.M.; Xia, Y.-R.; Wang, X.-P.; Miller, E.; Castellani, L.W.; Subbanagounder, G.; Cheroutre, H.; Faull, K.F.; Berliner, J.A.; Witztum, J.L.; et al. Combined Serum Paraoxonase Knockout/Apolipoprotein E Knockout Mice Exhibit Increased Lipoprotein Oxidation and Atherosclerosis. J. Biol. Chem. 2000, 275, 17527-17535. [CrossRef] [PubMed]

15. Tward, A.; Xia, Y.-R.; Wang, X.-P.; Shi, Y.-S.; Park, C.; Castellani, L.W.; Lusis, A.J.; Shih, D.M. Decreased Atherosclerotic Lesion Formation in Human Serum Paraoxonase Transgenic Mice. Circulation 2002, 106, 484-490. [CrossRef] [PubMed]

16. Bhattacharyya, T. Relationship of Paraoxonase 1 (PON1) Gene Polymorphisms and Functional Activity with Systemic Oxidative Stress and Cardiovascular Risk. JAMA 2008, 299, 1265-1276. [CrossRef] [PubMed]

17. Kunutsor, S.K.; Bakker, S.J.; James, R.W.; Dullaart, R.P. Serum paraoxonase-1 activity and risk of incident cardiovascular disease: The PREVEND study and meta-analysis of prospective population studies. Atheroscler. 2016, 245, 143-154. [CrossRef]

18. Menini, T.; Gugliucci, A. Paraoxonase 1 in neurological disorders. Redox Rep. 2014, 19, 49-58. [CrossRef]

19. Li, H.; Wetten, S.; Li, L.; Jean, P.L.S.; Upmanyu, R.; Surh, L.; Hosford, D.; Barnes, M.R.; Briley, J.D.; Borrie, M.; et al. Candidate Single-Nucleotide Polymorphisms from a Genomewide Association Study of Alzheimer Disease. Arch. Neurol. 2008, 65, 45-53. [CrossRef]

20. Erlich, P.M.; Lunetta, K.L.; Cupples, L.A.; Abraham, C.R.; Green, R.C.; Baldwin, C.T.; Farrer, L.A. Serum paraoxonase activity is associated with variants in the PON gene cluster and risk of Alzheimer disease. Neurobiol. Aging 2012, 33, 1015.e7-1015e23. [CrossRef]

21. Bednarska-Makaruk, M.; Krzywkowski, T.; Graban, A.; Lipczyńska-Łojkowska, W.; Bochyńska, A.; Rodo, M.; Wehr, H.; Ryglewicz, D.K. Original article Paraoxonase 1 (PON1) gene -108C >T and p.Q192R polymorphisms and arylesterase activity of the enzyme in patients with dementia. Folia Neuropathol. 2013, 2, 111-119. [CrossRef] [PubMed]

22. Borowczyk, K.; Shih, D.M.; Jakubowski, H. Metabolism and Neurotoxicity of Homocysteine Thiolactone in Mice: Evidence for a Protective Role of Paraoxonase 1. J. Alzheimer's Dis. 2012, 30, 225-231. [CrossRef] [PubMed]

23. Humbert, R.; Adler, D.A.; Disteche, C.M.; Hassett, C.; Omiecinski, C.J.; Furlong, C.E. The molecular basis of the human serum paraoxonase activity polymorphism. Nat. Genet. 1993, 3, 73-76. [CrossRef] [PubMed]

24. Perla-Kajan, J.; Jakubowski, H. Paraoxonase 1 protects against protein N-homocysteinylation in humans. FASEB J. Off. Publ. Fed. Am. Soc. Exp. Biol. 2010, 24, 931-936. [CrossRef]

25. Sikora, M.; Lewandowska, I.; Marczak, Ł.; Bretes, E.; Jakubowski, H. Cystathionine $\beta$-synthase deficiency: Different changes in proteomes of thrombosis-resistant $\mathrm{Cbs}^{-1-}$ mice and thrombosis-prone $\mathrm{CBS}^{-1-}$ humans. Sci. Rep. 2020, 10, 10726. [CrossRef]

26. Ganfornina, M.D.; Carmo, S.D.; Lora, J.M.; Torres-Schumann, S.; Vogel, M.; Allhorn, M.; Gonzalez, C.; Bastiani, M.J.; Rassart, E.; Sanchez, D. Apolipoprotein D is involved in the mechanisms regulating protection from oxidative stress. Aging Cell 2008, 7, 506-515. [CrossRef]

27. Elsøe, S.; Ahnström, J.; Christoffersen, C.; Hoofnagle, A.N.; Plomgaard, P.; Heinecke, J.W.; Binder, C.J.; Björkbacka, H.; Dahlbäck, B.; Nielsen, L.B. Apolipoprotein M binds oxidized phospholipids and increases the antioxidant effect of HDL. Atherosclerosis 2012, 221, 91-97. [CrossRef] 
28. Birch, N.P.; Browett, P.J.; Coughlin, P.B.; Horvath, A.J.; Van De Water, N.S.; Ockelford, P.A.; Harper, P.L.; Young, L.K. Two missense mutations identified in venous thrombosis patients impair the inhibitory function of the protein $\mathrm{Z}$ dependent protease inhibitor. Thromb. Haemost. 2012, 107, 854-863. [CrossRef]

29. Muszbek, L.; Bereczky, Z.; Bagoly, Z.; Komáromi, I.; Katona, É. Factor XIII: A Coagulation Factor with Multiple Plasmatic and Cellular Functions. Physiol. Rev. 2011, 91, 931-972. [CrossRef]

30. Pruissen, D.M.O.; Slooter, A.J.C.; Rosendaal, F.R.; Van Der Graaf, Y.; Algra, A. Coagulation factor XIII gene variation, oral contraceptives, and risk of ischemic stroke. Blood 2008, 111, 1282-1286. [CrossRef]

31. Tang, W.H.W.; Hartiala, J.; Fan, Y.; Wu, Y.; Stewart, A.F.; Erdmann, J.; Kathiresan, S.; Roberts, R.; McPherson, R.; Allayee, H.; et al. Clinical and Genetic Association of Serum Paraoxonase and Arylesterase Activities with Cardiovascular Risk. Arter. Thromb. Vasc. Biol. 2012, 32, 2803-2812. [CrossRef] [PubMed]

32. Suchon, P.; Trégouët, D.-A.; Morange, P.-E. Genetics of Venous Thrombosis: Update in 2015. Thromb. Haemost. 2015, 114, 910-919. [CrossRef] [PubMed]

33. Unsworth, A.J.; Flora, G.D.; Sasikumar, P.; Bye, A.P.; Sage, T.; Kriek, N.; Crescente, M.; Gibbins, J.M. RXR Ligands Negatively Regulate Thrombosis and Hemostasis. Arter. Thromb. Vasc. Biol. 2017, 37, 812-822. [CrossRef] [PubMed]

34. Suszyńska-Zajczyk, J.; Sikora, M.; Jakubowski, H. Paraoxonase 1 deficiency and hyperhomocysteinemia alter the expression of mouse kidney proteins involved in renal disease. Mol. Genet. Metab. 2014, 113, 200-206. [CrossRef] [PubMed]

Publisher's Note: MDPI stays neutral with regard to jurisdictional claims in published maps and institutional affiliations.

(C) 2020 by the authors. Licensee MDPI, Basel, Switzerland. This article is an open access article distributed under the terms and conditions of the Creative Commons Attribution (CC BY) license (http://creativecommons.org/licenses/by/4.0/). 